\title{
FORUM
}

Submitted 10.01.2018. Approved 07.19.2019

Evaluated through a double-blind review process. Guest Scientific Editors: Eduardo de Rezende Francisco, José Luiz Kugler, Soong Moon Kang, Ricardo Silva, and Peter Alexander Whigham

Original version

DOI: http://dx.doi.org/10.1590/So034-759020190604

\section{INFORMATION MANAGEMENT CAPABILITY AND BIG DATA STRATEGY IMPLEMENTATION}

\author{
Capacidade de gestão da informação e implementação de estratégia de Big Data \\ Capacidad de gestión de la información e implementación de estrategia de Big Data
}

\begin{abstract}
Firms are increasingly interested in developing Big Data strategies. However, the expectation of the value of these benefits and of the costs involved in acquiring or developing these solutions are not homogeneous for all firms, which generates competitive imperfections in the market for strategic resources. Information Management Capability (IMC) aims to provide the required unique insights for successful Big Data strategies. This study analyzes IMC as an imperfection agent in the market for strategic Big Data resources. The hypotheses were tested using a survey of 101 respondents and analyzed with SEM-PLS. The results indicate the positive influence of IMC on value expectation and a negative effect on cost expectation. Cost expectation inversely affects the intent to purchase or develop the resources to implement Big Data strategies. Value expectation has a positive effect on both intents.
\end{abstract}

KEYWORDS | Big Data, information management, strategic factor market, value expectation, cost expectation.

\section{ANTONIO CARLOS GASTAUD MAÇADA $^{1}$}

acgmacada@ea.ufrgs.br

ORCID: 0000-0002-8849-0117

RAFAEL ALFONSO BRINKHUES²

rafael.brinkhues@viamao.ifrs.edu.br

ORCID: 0000-0002-9367-5829

\section{JOSÉ CARLOS DA SILVA FREITAS JUNIOR ${ }^{3}$}

freitas1995@gmail.com

ORCID: 0000-0002-9050-1460

${ }^{1}$ Universidade Federal do Rio Grande do Sul, Escola de Administração, Porto Alegre, RS, Brazil

2Instituto Federal de Educação, Ciência e Tecnologia do Rio Grande do Sul, Viamão, RS, Brazil

3Universidade do Vale do Rio dos Sinos, Escola de Gestão e Negócios, São Leopoldo, RS, Brazil

\section{RESUMO}

O interesse das organizações em desenvolver estratégias de Big Data está aumentando significativamente. No entanto, a expectativa do valor desses benefícios e dos custos envolvidos na aquisição ou desenvolvimento dessas soluções não é homogênea para todas as empresas, gerando imperfeições competitivas no mercado de recursos estratégicos. A Capacidade de Gestãoda Informação (CGI) tem como premissa fornecer as informações necessárias para que as estratégias de Big Data sejam bem-sucedidas. Este artigo se propõe a analisar o CGI como um agente imperfeito no Strategic Factor Market de Big Data. As hipóteses foram testadas a partir de uma pesquisa de 101 respondentes e analisadas com a utilização de SEM-PLS. Os resultados indicam uma influência IMC positiva na expectativa de valor e uma negativa na expectativa de custo. A expectativa de custo afeta inversamente a intenção de comprar ou desenvolver os recursos para implantar estratégias de Big Data. A expectativa de valor tem um efeito positivo em ambas as intenções.

PALAVRAS-CHAVE I Big Data, gestão da informação, strategic factor market, expectativa de valor, expectativa de custo.

\section{RESUMEN}

El interés de las organizaciones en el desarrollo de estrategias de Big Data está aumentando significativamente. Sin embargo, la expectativa del valor de los beneficios y de los costos implicados en el acreedor o el desarrollo de estas soluciones no es homogénea para todas las empresas, impugnando las imperfecciones en el mercado de los recursos estratégicos. Capacidad de Gestión de la Información (CGI) utiliza las premisas proporcionar las pruebas requeridas para el éxito de Big Data, este artículo tiene como objetivo analizar el CGI como un agente de imperfección en el Strategic Factor Market de Big Data. Las hipótesis se probaron de una encuesta de 101 respondedores y se analizaron con SEM-PLS. Los resultados indican la positiva influencia de CGI sobre la expectativa y una negativa en una expectativa de los costos. La expectativa de los costos inversamente afecta al intento de comprar o de desarrollar los recursos para implementar estrategias Big Data. La expectativa de valor tiene un efecto positivo en ambos intents.

PALABRAS-CLAVES I Big Data, information management, strategic factor market, expectativa de valor, expectativa de los costos. 


\section{INTRODUCTION}

"Big Data is possibly the most significant 'tech' disruption in business and academic ecosystems since the meteoric rise of the Internet and the digital economy" (Agarwal \& Dhar, 2014, p. 443). Diverse forms of data that do not generate value do not contribute to an organization. Data value is, thus, driving increasing interest in big data (Chiang, Grover, Liang, \& Zhang, 2018). Researchers and technology vendors recognize the benefits of adopting big data analytics in business practices (Wang, Kung, Wang, \& Cegielski, 2018). Firms are increasingly interested in developing Big Data strategies (Tabesh, Mousavindin, \& Hasani, 2019). The percentage of firms that already invest or plan to invest in Big Data grew from 64 percent in 2013 (Gartner, 2014) to 73 percent (Davenport \& Bean, 2018). “Organizations are currently looking to adopt Big Data technology, but are uncertain of the benefits it may bring to the organization and concerned with the implementation costs" (Lakoju \& Serrano, 2017, p. 1). The volume of investments is growing at an even greater rate. The Big Data technology and services market will grow at an 11.9 percent compound annual growth rate (CAGR) to 260 billion dollars through 2022 (IDC, 2018). The expected organizational impacts are many, and include cost reductions, an increase in business insights, revelations of strategic information, and improved decision making (Kwon, Lee, \& Shin, 2014). However, the expected value of these benefits and the costs involved to acquire and develop these solutions are not homogeneous for every firm, which generates competitive imperfections in the market for strategic resources.

According to strategic factor market (SFM) theory, firms need to be consistently more informed than are other firms that aim to implement the same strategy to obtain superior performance (Barney, 1986). The author affirms that analyzing the firm's capabilities can create these circumstances more so than the competitive environment. We argue that information management capability (IMC) can bring the unique insight required for successful Big Data strategies. We define IMC as the firm's ability to access data and information from internal and external environments, to map and distribute data for processing, and to allow the firm to adjust to meet the market needs and directions. The literature indicates that IMC positively influences a firm's performance directly (Carmichael, Palácios-Marques, \& Gil-Pichuan, 2011) or is mediated by other organizational capabilities (Mithas, Ramasubbu, \& Sambamurthy, 2011). There is no evidence that a firm's current IMC can accommodate the sharp growth in the flow of unstructured data (White, 2012).

However, IMC can have a relevant role in the expectations for and intent to implement a strategy to deal with Big Data. Many practitioners are seeking such opportunities due to easy access to computational capabilities and analytical software (Agarwal \& Dhar, 2014). On the other hand, 43 percent of directors refer to budget deficits as the main barrier delaying the actions to take advantage of this context (Mckendrick, 2013). This indicates symmetry in the cost expectation of the resources for a Big Data strategy. From an academic standpoint, many studies investigate this phenomenon, especially in Information Systems (IS) in terms of analyzing the value creation from these data (e.g., Brown, Chui, \& Manyika, 2011; Davenport, Barth \& Bean, 2012; Johnson, 2012; McAfee \& Brynjolfsson 2012, Lakoju \& Serrano, 2017).

Nevertheless, few works focus on the relationship between IMC and Big Data in order to obtain this value (Brinkhues, Maçada, \& Casalinho, 2014; Mohanty, Jagadeesh, \& Srivatsa, 2013). "The current literature on big data value realization is characterized by a limited number of empirical studies and some repackaging of old ideas" (Günther, Rezazade Mehrizi, Huysman, \& Feldberg, 2017). This study aims to determine how the variation in the level of IMC among the firms creates competitive imperfections in the resources market for the implementation of Big Data strategies. To cover this research gap, we propose a scale to measure IMC and conceptually develop a research model to evaluate the relationship between IMC and the implementation of Big Data strategy empirically. This model, based on SFM theory, specifically investigates the influence of IMC on the value and cost expectations of the resources needed for this implementation, and based on transaction cost theory, the effect of these expectations on the intent to acquire or develop these resources. We constructed the scale following the literature and collect data from executives via card sorting. We tested the research model through a survey of 101 directors and analyze the data utilizing SEM-PLS.

This article proceeds as follows. The next section develops the hypotheses and presents the research model. The following section details the procedures to construct the IMC scale and for data collection. We present and discuss the results thereafter, and finally offer our conclusions and implications for research and managerial practice.

\section{INFORMATION MANAGEMENT CAPABILITY (IMC) AND THE STRATEGIC FACTOR MARKET (SFM)}

"Strategic Factor Markets (SFM) are markets where the necessary resources for implementation of a strategy are acquired" (Barney 1986, p. 1231); thus, firms can only extract superior performance when SFM is imperfect due to the differences in the expectation of 
the future value of these strategic resources. In other words, firms must be able to exploit a larger value of the necessary resources for its strategic implementation rather than the costs to acquire them being significantly less than their economic value. "The goal of big data programs should be to provide enough value to justify their continuation while exploring new capabilities and insights" (Mithas, Lee, Earley, Murugesan, \& Djavanshir, 2013, p. 18). To obtain this advantage, firms need to be consistently better informed than the other firms acting in the same SFM (Barney, 1986). IMC can serve as leverage in this advantage.

Mithas et al. (2011) propose the IMC construct to develop a conceptual model linking it with three other organizational capabilities (customer management, process management, and performance management). Their results show that these management capabilities mediate the positive influence of IMC on the firm's performance. Mithas et al.'s (2011) IMC concept consists of three abilities: to provide data and information to users with appropriate levels of accuracy, timeliness, reliability, security, and confidentiality; to provide connectivity and universal access at an adequate scope and scale; and to adapt the infrastructure to the emerging needs and directions of the market. Carmichael et al. (2011) define IMC as a second-order construct composed of the compilation and production of information; access to information; and the identification of information distribution requirements. Another author, Phadtare (2011), proposes that IMC is linked to five factors: acquisition and retention, processing and synthesis, recovery and use, transmission and dissemination, and support system and integration.

Based on the three works above (Mithas et al., 2011; Phadtare, 2011; Carmichael et al., 2011), we identify five dimensions of IMC (access, distribution, people, architecture, and infrastructure). Then, as we explain in detail in the next sections, we perform a card sorting analysis with executives, which pointed to a 10-item scale of these dimensions. From this analysis, we formulated a definition of IMC and applied in this study as corresponding to the firm's set of skills that articulate information infrastructure, the architecture of information, and access to information, which enable organizational adjustment in response to changes imposed by internal and external environments. Thus, we expect that organizations with more developed IMC are more accurate in their expectations of value and can take advantage of the asymmetry of information in the SFM, from which competitive imperfections in SFM derive.

Additionally, we expect that companies that developed IMC at a higher level during one of the previous eras of IM - Decision Support, Executive Support, Online Analytical Processing, and Business Intelligence and Analytics (Davenport, 2014) - have a higher value expectation of the next frontier of Big Data. We predict this result because the development of IMC at an elevated level positively impacts organizational performance (Carmichael et al., 2011; Mithas et al., 2011), which favors a polarizing effect of perceptions between past and present (Vasconcelos, Mascarenhas, $\&$ Vasconcelos, 2006). Big Data strategy is a set of solutions based on recent advances in Big Data analytics. Organizations seek to incorporate these solutions in their own decision-making processes successfully (Tabesh et al., 2019). Hence, these firms have a greater expectation of value from Big Data strategies based on their positive experiences with prior IM investments. Conversely, firms that did not reach the same level of IMC may not have had the same success in their ventures in $I M$, and this negative experience may reflect in a greater expectation of the cost to adopt this type of strategy.

$\mathrm{H}$ 1: Firms with more elevated IMC have a lower cost expectation to implement a Big Data strategy.

$\mathrm{H} 2$ : Firms with more elevated IMC have greater expectations of value extraction from implementing a Big Data strategy.

\section{Asymmetric value expectation and intent to purchase/develop Big Data strategy capabilities}

Prior studies also demonstrate the positive effect of using data for the purpose of acquiring Big Data solutions (Kwon et al., 2014). However, firms can also develop the resources and capabilities to implement a Big Data strategy internally.

Organizations exist to realize internal transactions more efficiently than it is to do so in the market (Coase, 1937). Accordingly, firms that do not arrange their resources to reach their objectives more efficiently than the market lose their reason to exist. Thereby, the search for the necessary resources to implement a Big Data strategy can go down two paths: to develop them internally or to acquire them in the market. Organizations can develop the necessary capabilities internally for this implementation if they are efficient in rearranging the resources involved. However, if the cost to acquire such funds in the market is less than the value to produce them internally, then firms tend to acquire them.

Transactions costs are the consequence of the asymmetrical and incomplete distribution of information among the organizations involved in the exchange (Cordella, 2006). The emergence of various suppliers with solutions to manage Big Data leaves uncertainty about what value firms can exploit from these resources. Thus, the decision to buy or develop the factors necessary to implement a Big Data strategy is also affected by the differences in the asymmetrical expectations of value that the firm can extract from this investment. We expect that different levels of expectations positively influence 
both decisions, whether to purchase or internally develop the resources to extract value from Big Data.

Hза: Firms with greater value extraction expectations of Big Data strategies have a higher purchase intent for these solutions.

$\mathrm{H}_{3}$ b: Firms with greater value extraction expectations of Big Data have a higher intent to develop these solutions internally.

\section{Asymmetric cost expectation and intent to purchase or develop Big Data strategy capabilities}

Resources such as million instructions per second (MIPS) and terabytes of storage for structured data are less expensive through Big Data technologies than through traditional technologies (Davenport, 2014). However, the costs of other less tangible resources may be more difficult to predict.

For instance, transaction costs frequently increase when adopting an IS solution. However, firms can reduce these costs when the costs associated with adoption do not exceed the external costs that affect adoption (Cordella, 2006).
Just as we expect to see companies with better developed IMC to have a lower expectation of the costs necessary to employ a Big Data strategy, it is also likely that this prediction of reduced costs favors a greater predisposition toward implementation. Additionally, with a more accurate cost expectation, companies with an elevated IMC level can create an adequate strategy within their budgets. We also expect the opposite effect: firms with less developed IMC will tend to have less exact cost predictions and therefore greater uncertainty when deciding whether to buy or develop resources to implement a Big Data strategy.

H4a: Firms with greater expectations of the costs to implement Big Data strategies have less purchase intent for these solutions.

$\mathrm{H}_{4} \mathrm{~b}$ : Firms with greater expectations of the cost to implement Big Data strategies have less intent to develop these solutions internally.

Considering the four-hypothesis developed above, we built the Research Model. An illustrated presentation of this can be seen in Figure 1.

Figure 1. Research Model

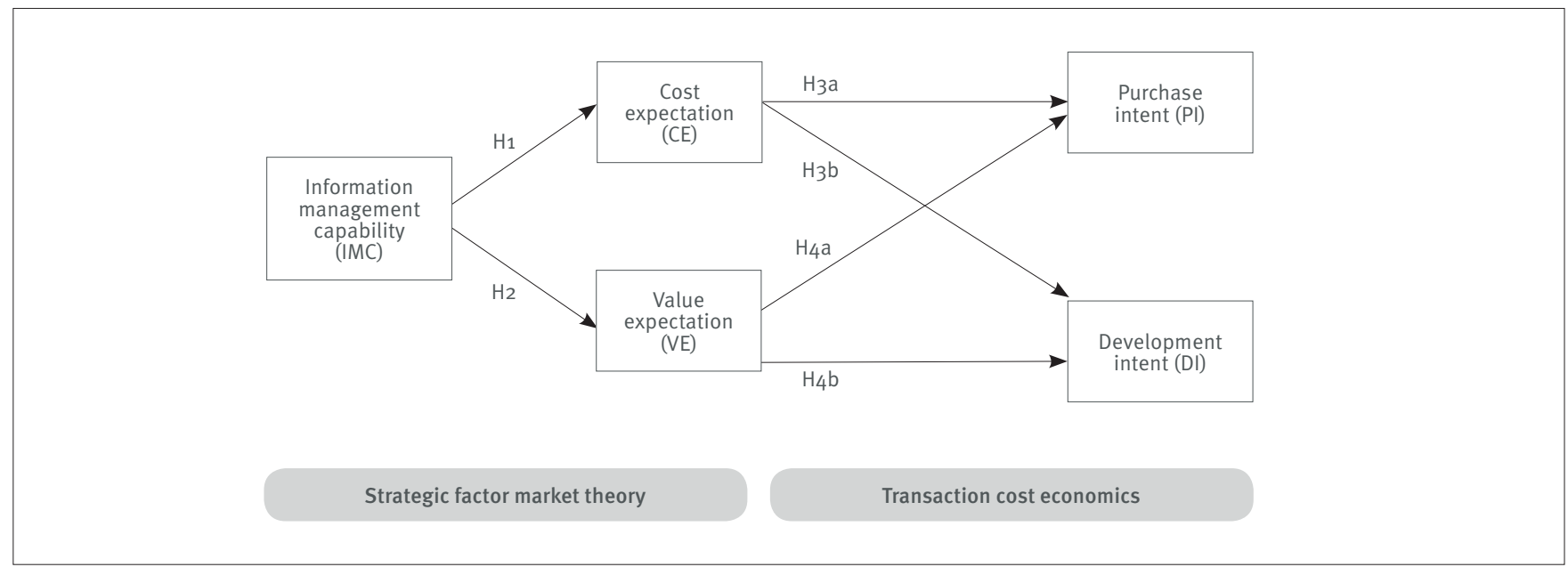

\section{RESEARCH METHODOLOGY}

We tested the hypotheses utilizing partial least squares structural equation modeling (PLS-SEM) based on survey data. PLS-SEM is frequently recommended for research in management because data in this field often do not adhere to a multi-varied normal distribution, while the models are complex and can still be informative. It is also recommended for smaller samples and models with less prior support (Ringle, Silva, \& Bido, 2014;
Hair, Hult, Ringle, \& Sarstedt, 2013). In light of the involved variables and the nature of this research, we consider the use of this statistical technique appropriate for empirically testing the hypotheses of the conceptual model.

However, we conducted a preliminary stage with a survey and Card Sorting analysis to propose a scale to measure IMC. We describe this stage in the next section, followed by the steps and details about the sample, data collection, and validation. 


\section{Card sorting to create an IMC scale}

We adapted a scale to measure IMC in the quantitative phase through a survey. This scale was based on existing research instruments (Carmichael et al., 2011; Mithas et al., 2011). The need to construct an IMC scale that could handle this new data environment did not influence the other variables, which already have tested scales.

For the scale, we applied the Optimal Workshop tool to perform a Card Sorting with 10 IT executives. Each online participant took an average of seven minutes to complete. Based on the card sorting results, we reduced the scale from 20 items across five dimensions (people, distribution, access, infrastructure, and information architecture) to 10 items by analyzing a matrix in which we used the cut above 60 percent similarity. To evaluate the dimensions, we used a dendrogram analysis for the best merge method, which often outperforms the actual agreement method when a survey has fewer participants. It makes assumptions about more massive clusters based on individual pair relationships (Optimal WorkShop, 2017). The scores of the cut represent 40 percent of the participants who agree with parts of this grouping. Five dimensions emerged from the group of scale-items assessed by the executives, which were in turn selected from the existing literature. We collected this group through Card Sorting analysis and named them based on the gathered items (people, distribution, access, infrastructure, and information architecture) in line with the authors' analysis of the results from the preliminary stage of the study.

We thus developed the IMC scale for this study. We developed this scale because in-depth research about this construct (Mithas et al., 2011) was validated from an adaptation from pre-existing secondary data, and to incorporate elements addressed in other works (Carmichael et al., 2011). The scales for the other variables of the research tool are adapted from the literature and modified as needed for this study. All items used a seven-point Likert scale (1-Strongly Disagree; 7 - Strongly Agree).
We conducted the statistical analysis using the SmartPLS version 3.2.0 software package.

\section{Sample frame and data collection}

We collected data through an online research created using the Google Forms platform. Data were collected through social networks, primarily through specific discussion groups about the addressed subjects. Some 29,282 people saw the notices, 208 people clicked on them, and we received 114 completed forms. The answer rate was 59 percent. Among these, we eliminated 13 through three validation questions inserted in the questionnaire to help with data quality control, leaving us with a final sample of 101 forms. Thus, the sample exceeds the minimum of 68 cases, for a power of 0.8 and a medium effect size $\mathrm{f}_{2}$ of 0.15 (Hair et al., 2013) with the variables at a maximum number of two predictors. We calculated this minimum sample using the $G *$ Power 3.1 tool (Faul, Erdfelder, Buchner, \& Lang, 2009).

The respondents were managers and executives in IT or other areas related to the implementation of IM strategies. Table 1 summarizes the profiles of the respondent firms, from which we can conclude that the sample is diversified and lightly focused on industry and size, whether through the number of employees or invoicing. The two most apparent differences in the size variable appear in the first two rows. In the first row, there is a smaller percentage of firms invoicing up to one million dollars ( $16 \%$ ), while the percentage of companies with up to 50 employees is 27 percent. In contrast, the second row presents a greater percentage of invoicing (23\% from 1 to 6.7 million dollars) and a smaller number of employees. A possible explanation for these differences may be in the high number of technological jobs, which have a high profitability potential with fewer employees. There were significant differences in the results relating to industry or firm size. In using Finite Mixture PLS, we did not identify latent classes that evidence the presence of groups within a sample.

Table 1. Respondent firms' profiles

\begin{tabular}{|c|c|c|c|c|c|}
\hline Industry & $\%$ & Number of employees & $\%$ & Annual revenue & $\%$ \\
\hline Technology & $24 \%$ & Up to 50 & $27 \%$ & Up to 1 million dollars & $16 \%$ \\
\hline Manufacturing & $18 \%$ & $51-100$ & $13 \%$ & 1 to 6.7 million dollars & $23 \%$ \\
\hline Financial services & $12 \%$ & $101-500$ & $11 \%$ & 6.7 to 37.5 million dollars & $14 \%$ \\
\hline Professional services & $11 \%$ & $501-1,000$ & $16 \%$ & 37.5 to 125 million dollars & $12 \%$ \\
\hline Others & $35 \%$ & More than 1,000 & $33 \%$ & More than 125 million dollars & $36 \%$ \\
\hline
\end{tabular}

Note: $n=101$ 


\section{RESULTS}

We first present an analysis of the results in terms of the measurement model, followed by an evaluation of the structural model.

\section{Evaluation of the measurement model}

We evaluated the measurement model through a series of reliability tests, including composite reliability (CR), Cronbach's alpha, average variance extracted (AVE), and discriminant validity (Hair et al., 2013; Ringle et al., 2014). As Table 2 shows, following Fornell and Larcker's (Henseler, Ringle, \& Sinkovics, 2009) criteria, the model converges, and the result is satisfactory because the AVE is above 0.50 for all variables.

Although the traditional indicator to evaluate internal consistency is Cronbach's alpha, CR is the best for PLS-PM because it is the least sensitive to the number of items in each construct (Ringle et al., 2014). In Table 2, we also see that all the variables present both indicators (Cronbach's alpha and CR) above 0.7. Therefore, all the variables are considered adequate and satisfactory (Hair et al., 2013). Also in Table 2, we report the Fornell and Larcker (1981) criteria to verify the discriminant quality according to the correlating values between the variables. The results indicate no correlation between distinct variables greater than the square root of the AVE of each variable (highlighted in gray in the main diagonal).

As the last criterion to evaluate the quality of the measurement model, we calculated discriminant validity utilizing a cross-loading analysis (Chin, 1998). In Table 3 we find no indicators with factor loadings below their variable than in others. Having attended to the quality criteria and discriminant validity of the model, we next evaluate the structural model in the next sub-section.

\section{Table 2. Quality Criteria}

\begin{tabular}{l|c|c|c|c|c|c|c|c}
\hline Variables & AVE & Composite reliability & Cronbach's Alpha & CE & DI & IMC & PI & VE \\
\hline Cost expectation & 0.778 & 0.875 & 0.715 & $\mathbf{0 . 8 8 2}$ & & & \\
\hline Development intent & 0.698 & 0.874 & 0.784 & -0.304 & $\mathbf{0 . 8 3 6}$ & & \\
\hline IMC & 0.548 & 0.923 & 0.907 & -0.407 & 0.258 & $\mathbf{0 . 7 4 0}$ & & \\
\hline Purchase intent & 0.657 & 0.851 & 0.747 & -0.405 & 0.735 & 0.300 & $\mathbf{0 . 8 1 1}$ & \\
\hline Value expectation & 0.819 & 0.901 & 0.780 & -0.392 & 0.318 & 0.647 & 0.360 & $\mathbf{0 . 9 0 5}$ \\
\hline Mean & & & & 4,75 & 3,26 & 4,18 & 3,40 & 5,16 \\
\hline SD & & & & 1,64 & 1,87 & 1,64 & 1,92 & 1,67 \\
\hline
\end{tabular}

Note: $C E=$ Cost expectation; $\mathrm{DI}=$ Development intent; IMC = Information management capability; PI = Purchase intent; VE = Value expectation.

\section{Table 3. Cross-Loadings}

\begin{tabular}{|c|c|c|c|c|c|}
\hline Items $\mathrm{x}$ Variables & IMC & CE & DI & $\mathrm{PI}$ & VE \\
\hline$I M C_{1}$ & 0.585 & -0.178 & 0.022 & 0.004 & 0.363 \\
\hline $\mathrm{IMC}_{2}$ & 0.757 & -0.255 & 0.236 & 0.263 & 0.459 \\
\hline $\mathrm{IMC}_{3}$ & 0.784 & -0.273 & 0.177 & 0.165 & 0.543 \\
\hline $\mathrm{IMC}_{4}$ & 0.823 & -0.347 & 0.319 & 0.351 & 0.656 \\
\hline $\mathrm{IMC}_{5}$ & 0.817 & -0.289 & 0.190 & 0.203 & 0.600 \\
\hline IMC6 & 0.697 & -0.182 & 0.033 & -0.048 & 0.349 \\
\hline IMC8 & 0.686 & -0.293 & 0.107 & 0.286 & 0.425 \\
\hline IMC9 & 0.711 & -0.417 & 0.125 & 0.191 & 0.337 \\
\hline $\mathrm{IMC}_{10}$ & 0.773 & -0.455 & 0.259 & 0.186 & 0.452 \\
\hline CE1 & -0.387 & 0.885 & -0.299 & -0.316 & -0.390 \\
\hline CE2 & -0.331 & 0.879 & -0.237 & -0.399 & -0.301 \\
\hline $\mathrm{Pl}_{1}$ & 0.253 & -0.285 & 0.826 & 0.819 & 0.305 \\
\hline $\mathrm{Pl} 2$ & 0.249 & -0.404 & 0.481 & 0.858 & 0.362 \\
\hline $\mathrm{Pl}_{3}$ & 0.229 & -0.269 & 0.517 & 0.751 & 0.166 \\
\hline VE1 & 0.557 & -0.361 & 0.325 & 0.362 & 0.907 \\
\hline VE2 & 0.615 & -0.349 & 0.250 & 0.289 & 0.903 \\
\hline
\end{tabular}




\section{Evaluation of the structural model}

To test the hypotheses and the predictive power of the model, we calculated Pearson's coefficients of determination (R2), the effect size $\left(f_{2}\right)$, predictive validity $\left(Q_{2}\right)$, and path coefficient $(r)$. According to Cohen's (1988) criteria, we can verify a medium effect of the model on the cost expectation (CE) (O.166) and development intent (DI) (o.139) variables, and a large effect on the value expectation (VE) (0.419) variable, and an almost large effect on the purchase intent (0.212) variable.

The bootstrapping analysis with 1,000 samples demonstrates that all the relations of the observable variables with the latent variables, and those among the latent variables, have significant correlations and regression coefficients at p<0.001, rejecting Ho. We then performed two other quality evaluations of the model adjustment, the predictive validity $\left(\mathrm{Q}_{2}\right)$ and the effect size ( $\left.f_{2}\right)$, through the blindfolding procedure. Table 4 shows that all Q2s are above zero, demonstrating the model's accuracy. The analysis of the effect size considers a medium utility of $\mathrm{CE}$, DI, and purchase intent (PI) to adjust the model. The results are close to an almost large utility of VE according to the criteria in Hair et al. (2013). Finally, the path coefficients, illustrated in Figure 2, show that the results support all hypotheses.

Table 4. Results of $\mathbf{R}^{2}, \mathbf{Q}^{2}$, and $\mathbf{f}^{2}$

\begin{tabular}{l|c|c|c}
\hline Relations & $\mathbf{R}^{2}$ & $\mathbf{Q}^{2}$ & $\mathbf{f}^{2}$ \\
\hline CE & 0.166 & 0.112 & 0.189 \\
\hline DI & 0.139 & 0.085 & 0.143 \\
\hline PI & 0.212 & 0.111 & 0.119 \\
\hline VE & 0.419 & 0.333 & 0.339 \\
\hline
\end{tabular}

Figure 2. Results of the empirical model: Path coefficients and $\mathbf{R}^{2}$

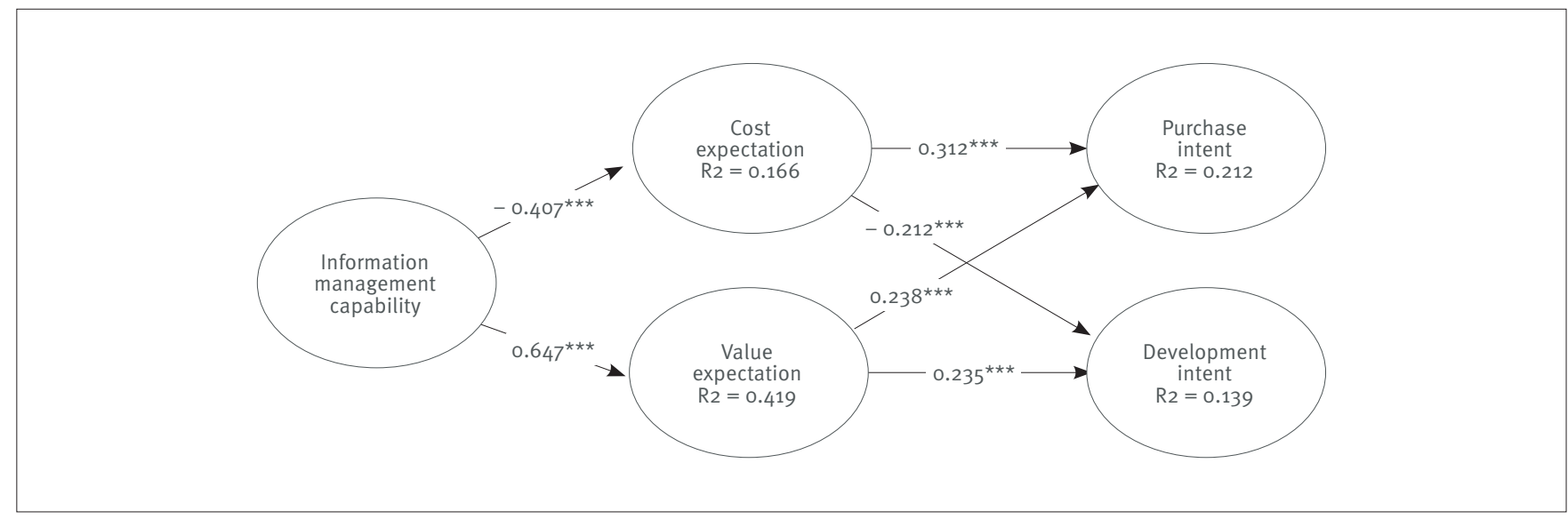

Note: * p<0.05; ${ }^{* *} p<0.01 ;{ }^{* * *} p<0.001$

According to the theoretical assumptions of SFM, $\mathrm{H}_{1}$ was confirmed since IMC had a negative impact on the CE of Big Data strategies; that is, the more developed a firm's IMC is, the lower the expectation of the expense to implement a Big Data strategy. The path coefficient analysis highlights that the IMC effect is even more evident on the VE expectation of these strategies. Hypothesis 2 was confirmed, indicating that this ability can be a potential source of imperfections in the SFM for Big Data in both cases.

The other half of the model $\left(\mathrm{H}_{3}\right.$ and $\left.\mathrm{H}_{4}\right)$ depicts the impact of the expectation to implement Big Data strategies in terms of the cost and value on the intention to purchase $\left(\mathrm{H}_{3}\right.$ and $\left.\mathrm{H}_{4}\right)$ and to develop ( $\mathrm{H}_{3} \mathrm{~b}$ ad $\mathrm{H}_{4} \mathrm{~b}$ ) these capabilities. Both hypotheses were confirmed. This impact was negative for Hypotheses $3 a$ (purchase) and $3 \mathrm{~b}$ (develop), demonstrating that a high cost expectation has a negative impact on the intent to purchase or develop Big Data strategies. The results also confirm Hypotheses $4 a$ and $4 \mathrm{~b}$. In other words, the intention to purchase or develop Big Data strategies was positive when the expectation of VE from a Big Data strategy was higher.

\section{FINAL CONSIDERATIONS}

We finalize this section with a discussion of the subject and an outline of future research directions.

\section{Contributions to research}

This paper contributes to the literature on management information systems by exploring a relatively recent theme (Big Data) and its relation to a firm's existing capability (IMC). 
Specifically, we analyzed this phenomenon by focusing on its impact on organizations. "This focus creates a tighter linkage between data and business models: we care deeply about business transformation and value creation through data, and less for algorithms or frameworks without a linkage to business value" (Agarwal \& Dhar, 2014, p. 445).

First, the research employed a rare theory in IS - SFM. This theory, along with transaction cost theory (widely used in IS), supported the development of the hypotheses and confirmed the statistical analysis. With this theoretical foundation and from the indications in the literature, it was possible to establish Hypothesis 1. Our results attest that IMC can have a negative impact on the expected cost of the necessary resources to implement a Big Data strategy. These results confirm that organizations have different cost expectations in the search for strategic resources (Barney 1986). IMC plays a relevant role in this heterogeneity of perceptions, whether through more accuracy (Mithas et al., 2011) in the access to and distribution of information, or the perceptive polarization effect (Vasconcelos et al., 2006). Companies that were not successfully able to develop IMC may have a higher expectation of the cost to implement a new strategy related to IM. However, this effect appears to be more strongly evident in the relationships in Hypothesis 2. We demonstrated that IMC positively impacts the expected value extraction from a Big Data strategy. This was the most elevated effect we found, which may indicate a product of the developed abilities or a reflex of successful experiences with IM.

On the other hand, we explained the impact of the expected cost on the intent of purchase or develop the resources and capabilities to implement a strategy to deal with voluminous and heterogeneous data through Hypotheses 3 a (purchase) and $3 b$ (develop). The negative impact was supported by empirical data demonstrating that a high cost expectation has an even more negative impact on purchase intent than on the intent to develop the resources and capabilities necessary for the strategy internally. Conversely, the results supported Hypothesis $4 \mathrm{CH}_{4} \mathrm{a}$ and $\mathrm{H}_{4} \mathrm{~b}$ ), showing that a greater expectation of future value extraction positively impacts the intent to purchase or develop Big Data strategies. In this case, the evidenced size effects for the intent to purchase or develop the required resources for these strategies were very similar. Nevertheless, this study did not aim to evaluate whether or not these expectations correspond to market reality. It is important to note that, in general, investments in IS strategies only reduce transaction costs if the firm consumes fewer resources than the economy generates (Ciborra, 1996).

Through two theoretical perspectives, our research contributes to our understanding of the impact that existing IMC may have on the adoption or non-adoption of new strategies in response to changes in information. More importantly, this study revealed the role of this capability as a potential source of imperfections in the SFM and may be a first step to investigating the role of IMC in the competitive performance of firms.

In addition, along with adopting the perspective of the IMC literature, we propose a new definition that is more in tune with the current context and the IM needs of organizations. We also proposed and validated a new scale to measure this construct.

\section{Implications for practice}

We can classify the implications of this study on practice for two types of organizations: those that look for solutions to respond to the environmental changes caused by Big Data and those that offer these solutions. For companies planning to implement Big Data strategies, the results reveal a large variation in the expectations of both the value and cost of the needed resources. This variation may reflect opportunities to search the market for underestimated resources or to incur the risk of acquiring overvalued resources. To reduce these risks and improve performance in the search to exploit these opportunities, our results show that investing in IM not only improves organizational performance (Carmichael et al., 2011; Mithas et al., 2011), it may also help firms evaluate future strategies.

From the other side of market, this work may serve firms that offer the resources and capabilities to implement Big Data strategies some insight into the expectations of their current or potential consumers. Understanding the differences in the perceptions of organizations with different levels of IMC may help firms create an adequate solution and contribute to the success of that solution in IMC development at greater levels for their clients.

\section{Limitations and future research}

Our study sample was very heterogeneous, as Table 1 shows, as we collected data non-systematically, and it may, thus, not entirely reflect the population of firms. It is also not possible to identify whether the results apply to a specific group of organizations. We measured the purchase intent and cost expectation constructs using only two indicators, and even though both presented good performance in terms of validity and reliability, it is still one indicator less than recommended.

This research opens the way for new investigations in IS, particularly related to IMC, the context of Big Data, and even new 
studies making use of SFM theory. Regarding IMC, we believe that future research may strengthen the strategic role of these capabilities, especially in this Big Data context. Researchers can use SFM to analyze other phenomena in the area and connect it to other theories in the IS literature. The model could hold true for IS strategies in general and can be investigated in the context of other technologies (such as business analytics or business intelligence).

\section{CONCLUSION}

This study, despite bringing in quantitative results, is exploratory given the nature of the content analyzed. We aimed to investigate how pre-existing IMC within organizations affects the expectations and intent of these firms in adopting a new IM strategy.

Our results offer insights into the effect on the relations between IMC and cost and future value expectation, in addition to the impact of these expectations on the intent to purchase or develop the needed resources to implement a Big Data strategy. Generally, the results unveiled that IMC positively influences value expectation and negatively influences cost expectation. Value expectation homogeneously and positively impacts the intent to purchase or develop these resources. Finally, cost expectation negatively influences development intent and, even more sharply, the purchase intent of the resources and capabilities for Big Data.

If one key resource for survival in this new environment is the ability to obtain access to more information and to be able to manage this information flow (Cordella, 2006), this research contributes to IS literature by exploring the potential of IMC in this Big Data context. From an academic standpoint, this study tested a less common theory in the literature, which researchers can explore further to analyze IS themes. Lastly, this research can help companies that supply Big Data solutions, as well as firms that intend to invest in strategies to deal with this change in the information environment.

\section{ACKNOWLEDGMENT}

The authors are grateful for the financial support provided by Conselho Nacional de Desenvolvimento Científico e Tecnológico (CNPq) and Coordenação de Aperfeiçoamento de Pessoal de Nível Superior (CAPES).

\section{REFERENCES}

Agarwal, R., \& Dhar, V. (2014). Editorial-Big Data, data science, and analytics: The opportunity and challenge for IS research. Information Systems Research, 25(3), 443-448. doi:10.1287/isre.2014.0546

Barney, J. (1986). Strategic factor markets: Expectations, luck, and business strategy. Management Science, 32(10), 1231-1241.

Brinkhues, R., Maçada, A., \& Casalinho, G. (2014). Information management capabilities: Antecedents and consequences. In Twentieth Americas Conference on Information Systems. Savannah, 1-11. Retrieved from https://pdfs.semanticscholar. org/1503/001cb9628f35acd727c4b31b02f613f6523c.pdf

Brown, B., Chui, M., \& Manyika, J. (2011). Are you ready for the era of "Big Data"? Retrieved from http://www.t-systems.com/solutions/ download-mckinsey-quarterly-/1148544_1/blobBinary/StudyMcKinsey-Big-data.pdf [Accessed November 23, 2014].

Carmichael, F., Palacios-Marques, D., \& Gil-Pechuan., I. (2011). How to create information management capabilities through web 2.0. The Service Industries, 31(10), 1613-1625. doi:10.1080/02642069.2010. 485635

Chiang, R. H. L., Grover, V., Liang, T.-P., \& Zhang, D. (2018). Special Issue: Strategic value of Big Data and business analytics. Journal of Management Information Systems, 35(2), 383-387. doi:10.1080/074 21222.2018.1451950

Chin, W. W. (1998). The partial least squares approach for structural equation modeling. In G. A. Marcoulides (Ed.), Modern methods for business research (pp. 295-236). London, UK: Laurence Erlbaum Associates.

Ciborra, C. U. (1996). Teams, markets, and systems: Business innovation and information technology. New York, NY: Cambridge University Press.

Coase, R. H. (1937). The nature of the firm. Economica, 4(16), 386-405. doi:10.1111/j.1468-0335.1937.tboooo2.x

Cohen, J. (1988). Statistical power analysis for the behavioral sciences $2^{\text {nd }}$ ed. New Jersey, NJ: Lawrence Erlbaum Associates.

Cordella, A. (2006). Transaction costs and information systems: Does IT add up? Journal of Information Technology, 21(3), 195-202. doi:10.1057/palgrave.jit.2000066

Davenport, T. H. (2014). Big Data at work: Dispelling the myths, uncovering the opportunities. Boston, MA: Harvard Business School Publishing.

Davenport, T. H., Barth, P., \& Bean, R. (2012). How “Big Data” is different. Sloan Management Review, 54(1), 21-24.

Davenport, T. H., \& Bean, R. (2018). Data and innovation: How Big Data and Al are driving business innovation. New Vantage Partners LLC. Retrieved from https://newvantage.com/wp-content/ uploads/2018/01/Big-Data-Executive-Survey-2018-Findings.pdf

Faul, F., Erdfelder, E., Buchner, A., \& Lang, A. G. (2009). Statistical power analyses using $G^{*}$ Power 3.1: Tests for correlation and regression analyses. Behavior Research Methods, 41(4), 1149-1160. doi:10.3758/BRM.41.4.1149 
Fornell, C., \& Larcker, D. F. (1981). Evaluating structural equation models with unobservable variables and measurement error. Journal of Marketing Research, 18(1), 39-50. doi:10.2307/3151312

Gartner. (2014). Newsroom Gartner survey reveals that 73 percent of organizations have invested or plan to invest in Big Data in the next two years. Retrieved from http://www.gartner.com/newsroom/id/2848718

Günther, W. A., Rezazade Mehrizi, M. H., Huysman, M., \& Feldberg, F. (2017). Debating big data: A literature review on realizing value from big data. Journal of Strategic Information Systems, 26(3), 191-209. doi:10.1016/j.jsis.2017.07.003

Hair Jr, J. F., Hult, G. T. M., Ringle, C., \& Sarstedt, M. (2016). A primer on partial least squares structural equation modeling (PLS-SEM). Thousand Oaks, CA: Sage Publications.

Henseler, J., Ringle, C., \& Sinkovics, R. (2009). The use of partial least squares path modeling in international marketing. Retrieved from https://opus.lib.uts.edu.au/research/handle/10453/10057

International Data Corporation. (2018). Revenues for Big Data and business analytics solutions forecast to reach $\$ 260$ billion in 2022, Led by the banking and manufacturing industries, according to IDC. Retrieved from https://www.idc.com/getdoc. jsp?containerld=prUS44215218

Johnson, J. (2012). Big Data + Big Analytics = Big Opportunity. Financial Executive, 28(6), 50-53.

Kwon, O., Lee, N., \& Shin, B. (2014). Data quality management, data usage experience and acquisition intention of big data analytics. International Journal of Information Management, 34(3), 387-394. doi:10.1016/j.ijinfomgt.2014.02.002

Lakoju, M., \& Serrano, A. (2017). Framework for aligning Big-Data strategy with organizational goals. Proceedings of Twenty-third Americas Conference on Information Systems, Boston.

McAfee, A., \& Brynjolfsson, E. (2012). Big Data: The management revolution. MIT Sloan Management Review, 90(10), 61-68.
Mckendrick, J. (2013). 2013 Big Data opportunities survey. Unisphere Research. New Providence. http://www.unisphereresearch.com/ Issues/5375-Big-Data-Big-Challenges-Big-Opportunities-2012-IOUGBig-Data-Strategies-Survey.htm

Mithas, S., Lee, M., Earley, S., Murugesan, S., \& Djavanshir, R. (2013). Leveraging Big Data and business analytics. IT Professional, 15(6), 18-20. doi:10.1109/MITP.2013.95

Mithas, S., Ramasubbu, N., \& Sambamurthy, V. (2011). How information management capability influences firm performance. MIS Quarterly, 35(1), 237-256.

Mohanty, S., Jagadeesh, M., \& Srivatsa, H. (2013). The new information management paradigm. In S. Mohanty, M. Jagadeesh, \& H. Srivatsa, Big Data Imperatives (pp. 25-44). Berkeley, CA: Apress.

Optimal WorkShop (2017). Card sorting 101. Your guide to creating and running an effective card sort. Retrieved from https://www. optimalworkshop.com/101/card-sorting

Phadtare, M. (2011). Strategic management: Concepts and cases. New Delhi, India: PHI Learning Pvt. Ltd.

Ringle, C. M., Silva, D., \& Bido, D. de S. (2014). Modelagem de equações estruturais com utilização do Smartpls. Revista Brasileira de Marketing, 13(2), 56-73. doi:10.5585/remark.v13i2.2717

Tabesh, P., Mousavidin, E., \& Hasani, S. (2019). Implementing big data strategies: A managerial perspective. Business Horizons, 62(3), 347358. doi:10.1016/j.bushor.2019.02.001

Vasconcelos, I. F. G. De, Mascarenhas, A. O., \& Vasconcelos, F. C. De, (2006). Gestão do paradoxo "passado versus futuro": Uma visão transformacional da gestão de pessoas. RAE-Eletrônica, 5(1). Retrieved from https://rae.fgv.br/rae-eletronica/

Wang, Y., Kung, L. A., Wang, W. Y. C., \& Cegielski, C. G. (2018). An integrated big data analytics-enabled transformation model: Application to health care. Information and Management, 55(1), 64 79. doi:10.1016/j.im.2017.04.001

White, M. (2012). Digital workplaces: Vision and reality. Business Information Review, 29(4), 205-214. doi:10.1177/0266382112470412 